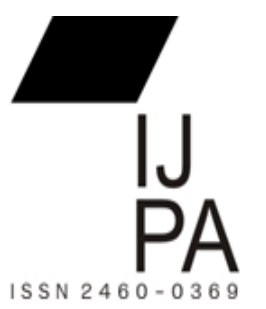

\title{
WUJUD INOVASI PENINGKATAN KUALITAS PELAYANAN KOTA TRENGGALEK DALAM TANGANI KEMISKINAN MELALUI PROGRAM GERTAK (GERAKAN TENGOK BAWAH MASALAH KEMISKINAN)
}

\section{Siti Nurauliyah Khaerunnisa}

\author{
Mahasiswa Jurusan Administrasi Publik, \\ Universitas 17 Agutsus 1945 Jakarta \\ snurauliyahkh@gmail.com
}

\begin{abstract}
The problem of poverty is now a very serious discussion. Not just for some countries, but in some areas has become the subject of discussion. The problem of poverty is also found in Trenggalek regency, the poverty that is encountered is not only about economy but poverty is also in the speed between rich and poor. Judging from some of the issues at Trenggalek, one of them is uneven and also the serious attention of the district government to combine this poverty. Similarly, it also affects the human-human in Trenggalek District. The local government should create a service facility for the change and its regional development. It is also implemented by the government of Trenggalek regency, where the problem of poverty is still high enough for Trenggalek regency government to find innovative solutions with the implementing program of GERTAK (Gerakan Tengok Bawah Kemiskinan). Through the program, Trenggalek District Government can be the solution of the poverty problem in Trenggalek. Trenggalek Regency is one of the areas implemented by GERTAK. The research method used to overcome GERTAK innovation is a qualitative method. From the research result, that is GERTAK give service of soccer aid to society in service implementation to be able to overcome or solve poverty problem and also social / human gap between rich and poor.
\end{abstract}

Keywords: Poverty, Innovation, Service 


\begin{abstract}
Abstrak, Masalah kemisikinan saat ini telah menjadi pembahasan yang sangat serius. Bukan hanya untuk beberapa Negara, namun dibeberapa daerah pun telah menjadi permasalahan pokok pembahasan. Permasalahan kemiskinan ini juga ditemui pada Kabupaten Trenggalek, kemiskinan yang ditemui pun tidak hanya perihal ekonomi namun kemiskinan tersebut juga berada pada kesenjangan antara kaya dan miskin. Melihat dari beberapa hal yang menjadi pokok masalah kemiskinan di Trenggalek, salah satu nya adalah tidak merata nya perekonomian dan juga perhatian serius dari pemerintah kabupaten untuk dapat menangani kemiskinan ini. Sehingga hal tersebut juga berdampak kepada kesenjangan sosial-manusia yang ada di Kabupaten Trenggalek. Pemerintah daerah harus mampu membuat inovasi program pelayanan untuk perubahan serta pembangunan daerah nya. Hal tersebut juga di implementasikan oleh pemerintah Kabupaten Trenggalek, dimana melihat masalah kemiskinan masih cukup tinggi sehingga pemerintah Kabupaten Trenggalek mencari solusi yang inovatif yakni dengan menerapkan program GERTAK (Gerakan Tengok Bawah Masalah Kesmiskinan). Melalui program tersebut, pemerintah Kabupaten Trenggalek berharap dapat menjadi solusi dari permasalahan kemiskinan di Trenggalek. Kabupaten Trenggalek adalah salah satu daerah yang melaksanakan GERTAK. Metode penelitian yang digunakan untuk meneliti inovasi GERTAK adalah metode kualitatif. Dari hasil penelitian, bahwa GERTAK memberikan layanan jemput bola pada masyarakat dalam pelaksanaan pelayanan untuk dapat menaggulangi atau menuntaskan masalah kemiskinan dan juga kesenjangan sosial/manusia antara kaya dan miskin.
\end{abstract}

Kata Kunci : Kemiskinan, Inovasi, Pelayanan

\title{
PENDAHULUAN
}

Dalam melakukan sebuah perubahan atau pembangunan baik secara insfrastruktur maupun pembangunan manusia tentu tidak akan mudah. Pada dasarnya sebuah pembangunan adalah kegiatan yang berlangsung secara terus menerus yang dilakukan oleh sebuah instansi/organisasi untuk mencapai tujuan yang lebih baik. Seperti yang dilakukan oleh Pemerintah Kabupaten Trenggalek dalam melakukan sebuah pembangunan dan juga perubahan baik secara bentuk pelayanan publik maupun administrasi untuk dapat mencapai tujuan yang lebih baik lagi. 
Memperhatikan sejak masa Pemerintahan Jokowi yang selalu menginstruksikan untuk melakukan pembangunan khusus nya pada wilayah pedesaan atau daerah kabupaten, hal tersebut menjadi sebuah dasar yang kuat dan juga sebagai penunjang serta motivasi untuk melakukan pembanguan. Untuk dapat melancarkan sebuah pembangunan, akhirnya pemerintah membuat suatu kebijakan atau perarturan mengenai otonomi daerah dimana pemerintah pusat menyerahkan sepenuh nya wewenang kepada pemerintahan daerah untuk dapat mengurus daerah serta menyelesaikan permasalahan daerah yang ada namun tidak terlepas atau bahkan melanggar Undang-Undang yang berlaku dengan kekhawatiran akan dapat merugikan masyarakat daerah. Karena, sebuah pembangunan juga diperuntukan untuk kesejahteraan masyarakat.

Bermula dari keluhan dan tuntutan dari masyarakat kepada pemerintah terhadap pelayanan publik yang selama ini dianggap kurang memuaskan dan perlu dibenahi. Keluhan terhadap pelayanan publik data dicontohkan dari pelayanan yang memakan waktu lama, tidak tepat waktu, kurangnya tanggungjawab petugas pelayanan, kurang transparan, masih banyak diskriminasi dalam proses pelayanan dan tidak jarang pelayanannya rumit dan terbelit-belit. Tuntutan dari masyarakat tidak lain yaitu pemerintah dituntut untuk bisa memperbaiki dan meningkatkan pelayanannya dengan baik agar timbul kembali kepercayaan masyarakat kepada pemerintah bahwa pemerintah dapat melayani masyarakat tanpa pamprih dan bersih. Dengan adanya keluhan dan tuntutan dari masyarakat, maka pemerintah melalui institusinya yaitu membuat suat trobosan atau ide tentang kebijakan inovatif pada pelayanan publik.

Pemerintah Kabupaten Trenggalek menemukan sebuah permasalahan yang sangat serius terkait dengan kemiskinan. Bahkan kemiskinan tersebut tidak hanya terjadi dalam sektor ekonomi namun berdampak kepada kesenjangan sosial/manusia. Memperhatikan mengenai otonomi daerah, akhirnya Kabupaten Trenggalek mencari sebuah solusi untuk dapat menekan angka kemiskinan dan juga dapat menyelesaikan tuntas perihal kemiskinan tersebut. Mengacu kepada UU No. 23 Tahun 2014 tentang Pemerintahan Daerah, dalam Bab XXI yang bertemakan Inovasi Daerah. Dua tahun sebelumnya, angka kemiskinan dari data yang didapatkan pada tahun 2015 sebanyak 267.274 jiwa sedangkan untuk tahun 2016 272. 792. Dengan data yang didapatkan serta melalui perbincangan panjang yang dilakukan oleh 
pemerintah Kabupaten Trenggalek dengan beberapa tokoh masyarakat dan juga pemerintah terkait maka dari itu pemerintah Kabupaten Trenggalek Membuat sebuah program yaitu GERTAK (Gerakan Tengok Bawah Masalah Kesmiskinan). Sebuah program pemerintah daerah yang direncakan bisa untuk menekan angka kemiskinan dan juga kesenjangan sosial/manusia pada Kabupaten Trenggalek.

Hal ini merupakan langkah nyata dan serius dari pemerintah Kabupaten Trenggalek dalam upaya mengatasi masalah kemiskinan. Sebelum membuat grogram GERTAK, pemerintah Kabupaten mencatat bahwa sekitar 3000 ribu warga miskin lansi itupun beragam kondisinya. Dimulai dari yang mempunyai rumah tapi tidak mempunyai keluarga (sebatang kara) atau bahkan sebalik nya. Hal tersebut yang memicu atau faktor utamanya kemiskinan di Kabupaten Trenggalek.

Diharapkan dengan berjalan nya serta konsistensi Pemerintah Kabupaten Trenggalek dalam melaksanakan program pelayanan tersebut akan berdampak besar bagi masyarakat Kabupaten Trenggalek, khususnya untuk dapat keluar dari permasalahan kemiskinan yang ada dan sudah sejak lama namun belum juga mendapatkan perhatian serta tindakan nyata dari pemerintahan sebelumnya. Selain itu keberhasilan program GERTAK juga sebagai salah satu terwujudnya Inovasi Pelayanan public untuk meningkatkan kualitas hidup masyarakat. Kabupaten Trenggalek karena telah mampu menyelesaikan permasalahan daerahnya dengan upaya berinovasi dalam membuat sebuah program dan penyelesaian masalah.

\section{KAJIAN TEORITIS}

\section{Inovasi Sektor Publik}

Tujuan dalam pelaksanaan inovasi sektor publik sesungguhnya yaitu adanya tuntutan akuntabilitas, transparansi dan perbaikan dalam hal pelayanannya kepada masyarakat. Sehingga dalam sektor publik seharusnya dapat bekerja lebih efektif, efisien, dan ekonomis. Dengan ini diharapkan agar kedepannya sebuah inovasi menjadi hal yang penting dilakukan bagi setiap instansi pemerintah dalam rangka percepatan pembangunan, perbaikan perekonomian serta peningkatan pelayanan publik kepada masyarakat. Inovasi sendiri diartikan sebagai kegiatan kajian, pengembangan, atau perekayasaan yang bertujuan 
mengembangkan penerapan praktis nilai dan konteks ilmu pengetahuan yang baru dan teknologi yang telah ada ke dalam produk atau proses produksi. Inovasi sektor publik terbagi menjadi lima tipologi yaitu inovasi produk atau layanan, inovasi proses layanan, inovasi metode layanan, inovasi kebijakan, inovasi sistem.

\section{Pelayanan Publik}

Menurut Robert (1996, h.30) pelayanan publik merupakan semua jenis kegiatan pelayanan umum yang dilaksanakan oleh instansi pemerintah pusat, di daerah, dan lingkungan badan usaha milik negara dalam upayanya memenuhi kebutuhan masyarakat. Sedangkan menurut Lewis dan Gilman (2005, h.22) pelayanan publik diartikan sebagai kepercayaan publik.

\section{METODE PENELITIAN}

Jenis penelitian yang digunakan dalam penelitian ini adalah penelitian deskriptif dengan pendekatan kualitatif. Jenis penelitian deskriptif dengan pendekatan kualitatif yang digunakan pada penelitian ini dimaksudkan untuk memperoleh informasi dengan cara memberikan penjelasan inovasi yang ada dalam program pelayanan GERTAK sebagai terwujudnya Inovasi Pelayanan public untuk meningkatkan kualitas hidup masyarakat. Analisis data yang dipergunakan dalam penelitian ini adalah menggunakan analisis Miles and Huberman.

\section{PEMBAHASAN}

Trenggalek merupakan salah satu daerah bersejarah di Jawa namun belum banyak masyarakat yang mengetahui Kabupaten Trenggalek. Kabupaten Trenggalek terbagi atas 14 Kecamatan. 152 Desa dan 5 kelurahan. Trenggalek juga salah satu kabupaten pesisir pantai di Jawa Timur. Meskipun Trenggalek berada pada pesisir pantai, Trenggalek juga merupakan daerah pegunungan namun tidak memiliki gunung yang aktif. Pada tahun 2015 Trenggalek menyelenggarakan pemilihan kepala Daerah yang dimenangkan mutlak oleh pasangan EmilIpin, namun ternyata masih terdapat pasrtisipasi yang rendah dari masyarakat dalam pilkada tersebut. Hal ini dibuktikan dengan tidak banyak nya masyarakat yang ikut berpastisipasi dalam pemilihan kepala daerah. Tercatat pada peristiwa pilkada bupati 2015 32,24 persen 
atau hampir sepertiga penduduk yang memiliki hal pilih namun tidak menggunakan hak pilih nya. Hal tersebut sedikit mencerminkan bahwa kesadaran masyarakat masih sangat rendah terlebih dalam berpasrtisipasi untuk pemilihan bupati, Kemudian aktifitas pemerintah yang dikerjakan juga membuat banyak terobosan yang dilakukan.

Kabupaten Trenggalek mempunyai banyak tempat peristirahatan dan tempat wisata yang mempunyai keindahan yang masih asli belum berubah oleh keadaan jaman, misalnya Gua. Mengingat di Kabupaten Trenggalek terdiri dari wilayah dengan bukit-bukit tinggi, memiliki medan yang relatif sulit dijangkau karena jalan yang terjar,masih berupa batu-batuan dan jalan yang berliku-liku. Contohnya saja Kecamatan Munjungan dengan 11 desanya yang berada pada selatan Trenggalek, kecamatan terakhir yang berdekatan langsung dengan pantai selatan Trenggalek.

Letaknya pun sekitar $40 \mathrm{~km}$ dari pusat Kantor Pertanahan Kabupaten Trenggalek dan ditempuh bisa sampai 1 jam setengah lebih dengan kondisi jalan yang kurang baik dan berliku-liku melintasi bukut-bukit tinggi. Keberadaan daerah-daerah ini yang jauh dari pusat kota tentunya menjadi masalah sendiri bagi masyarakat apabila ingin mengurus tanah mereka di kantor pertanahan. Selain jauh dan memakan waktu yang lama, mereka juga keterbatasan oleh alat transportasi sehingga mengurungkan masyarakat juga enggan dan malas untuk mensertifikasikan tanahnya (kurangnya kesadaran). Oleh karena itu, keberadaan GERTAK yang proaktif melalui program sedekah informasi dalam program GERTAK efektif dalam komitmen negara menjangkau penyandang masalah kesejahteraan sosial (PMKS)

\section{Kemiskinan}

Sebelumnya kemiskinan itu sendiri merupakan salah satu bentuk kekurangan yang dihadapi oleh mahkluk hidup. Baik dalam kekurangan daya beli maupun dalam penunjang kehidupan. Hidup dalam kemiskinan juga bukan hanya berkisar pada tingkat ekonomi yang rendah, namun juga bisa dapat bentuk miksin pengetahuan, miskin kesehatan dan miskin informasi. Selan itu, biasanya masyarakat miskin ditandai dengan kehidupan yang kurang dari pada biasanya, tidak memiliki pekerjaaan yang tetap, tidak memiliki ruang atau lahan sendiri untuk dikelola dan menghasilkan sebuah produksi sehingga memiliki daya jual. 
Untuk kabupaten Trenggalek sendiri, penduduk yang bekerja banyak didominasi oleh penduduk usia 60 tahun keatas yang tercatat lebih dari 17 persen. Produktifitas penduduk usia tua ini jelas kalah dibandingkan dengan usia produktif dibawahnya. Anak usia 15-19 tahun yang jumlahnya sekitar 2,27 persen juga banyak terlibat dalam bekerja dimana mereka seharusnya fokus dalam sekolah. Hal ini mengindikasikan bahwa tenaga kerja di Trenggalek mempunyai daya saing yang relatif rendah karena banyak didukung oleh pekerja dalam usia yang tidak produktif.

Lapangan pekerjaan pertanian, kehutanan, perburuan dan perikanan masih menjadi primadona sebagian besar perduduk yang bekerja, dimana lebih dari 52 persen menggantungkan nasib pada lapangan pekerjaan ini. Hal ini dapat dimaklumi, karena kondisi alam dan geografis yang sangat mendukung. Pertambangan dan penggalian merupakan lapangan pekerjaan yang kurang diminati yang hanya melibatkan kurang dari satu persen dari kekeseluruhan orang yang bekerja. Sementara itu daya saing SDM masyarakat Trenggalek masih perlu ditingkatkan lagi agar bisa bersaing dengan daerah lain. Dominasi lulusan SD masih sangatlah besar, yaitu lebih dari 42 persen.

Melihat kondisi geografis Kabupaten Trenggalek yang berada di pesisir pantai sepanjang jalur di Jawa Timur, serta memiliki beberapa gunung yang tidak aktif. Hal tersebut menjadi salah satu faktor masyarakat Kabupaten memilih untuk bekerja pada sektor pertanian dan perkebunan, namun hal tersebut juga bukan menjadi salah satu kekuatan untuk dapat menurunkan angka kemiskinan. Seperi biasa partisipasi masyarakat yang kurang, serta dipengaruhi oleh tingkat pendidikan yang rendah menjadi faktor penunjang masyarakat miskin. Kemudian perhatian yang kurang dari pemerintah untuk dapat mengelola dan memberikan pendidikan bagi masyarakat yang memiliki pendidikan rendah pun masih sangat kurang.

Selain itu faktor usia produktif masyarakat kabupaten Trenggalek juga menjadi salah satu masalah yang dihadapi. Karena sebagian besar dari masyarakat itu masih melanjutkan pendidikan dan mulai terfokus, tapi orang tua mereka terhalang dengan usia yang sudah tidak produktif lagi sehinga menjadi penghammbat dalam mendapatkan pendidikan yang lebih layak untuk masa depan generasi bangsa yang ada di Kabupaten Trenggalek. Hal tersebut lah 
yang memicu angka kemiskinan belum juga dapat diminimalisir oleh Kabupaten Trenggalek. Selain itu kembali lagi kepada peran pemerintah yang masih sangat kurang menaruh perhatian kepada masyarakat, serta belum adanya Inovasi Pelayanan atau sebuah program kegiatan yang dilakukan oleh Pemerintah Kabupaten Trenggalek kepada masyarakat untuk keluar dari kemiskinan dan bangkit dari keterpurukan. Berikut ini merupakan data kemiskinan dan juga faktor dari kemiskinan di Kabupaten Trenggalek :

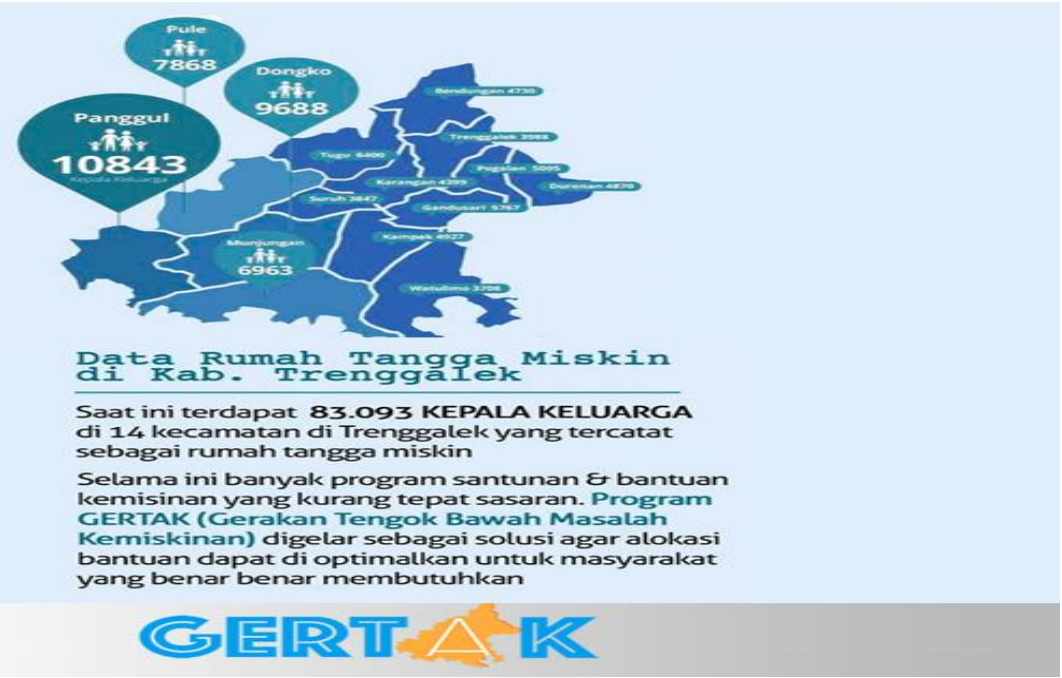

Sumber: http://poskogertak.id/datakemiskina/

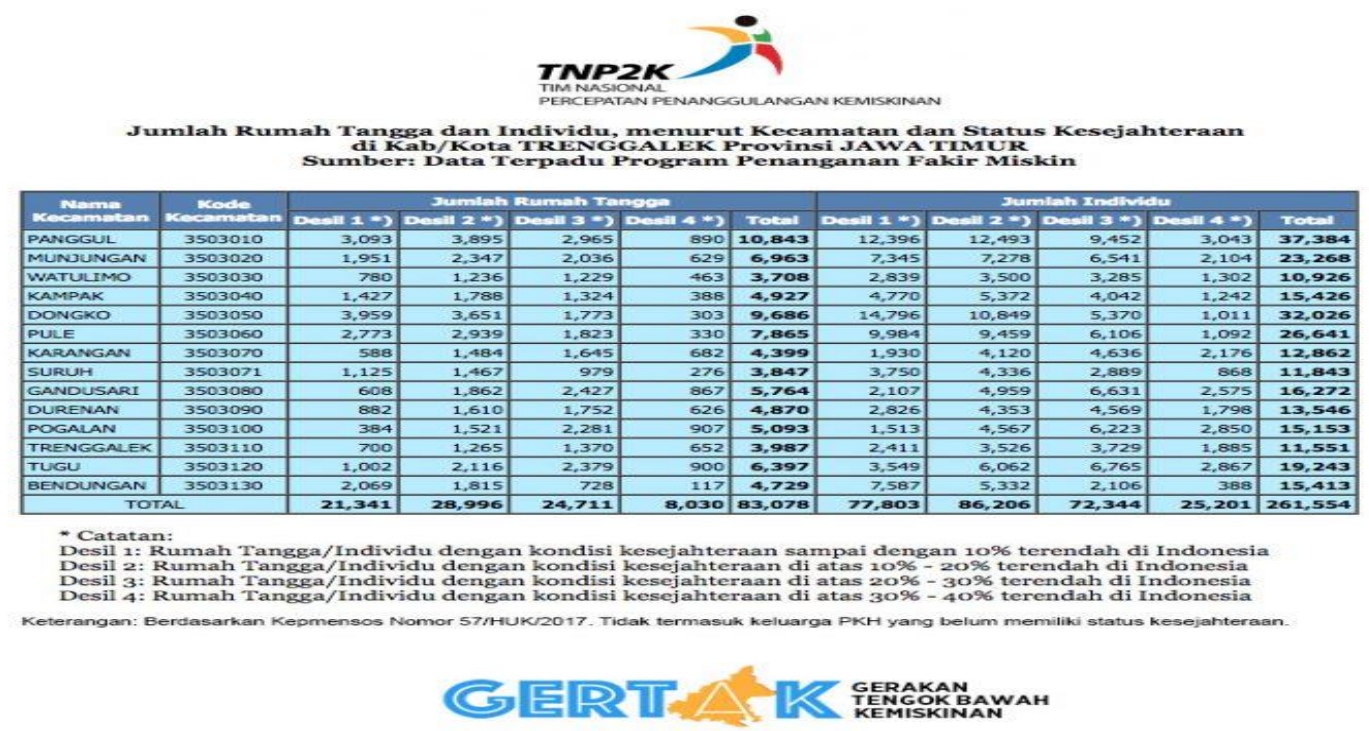

Sumber: http://poskogertak.id/jumlah-rumah-tangga-miskin-di-trenggalek/ 


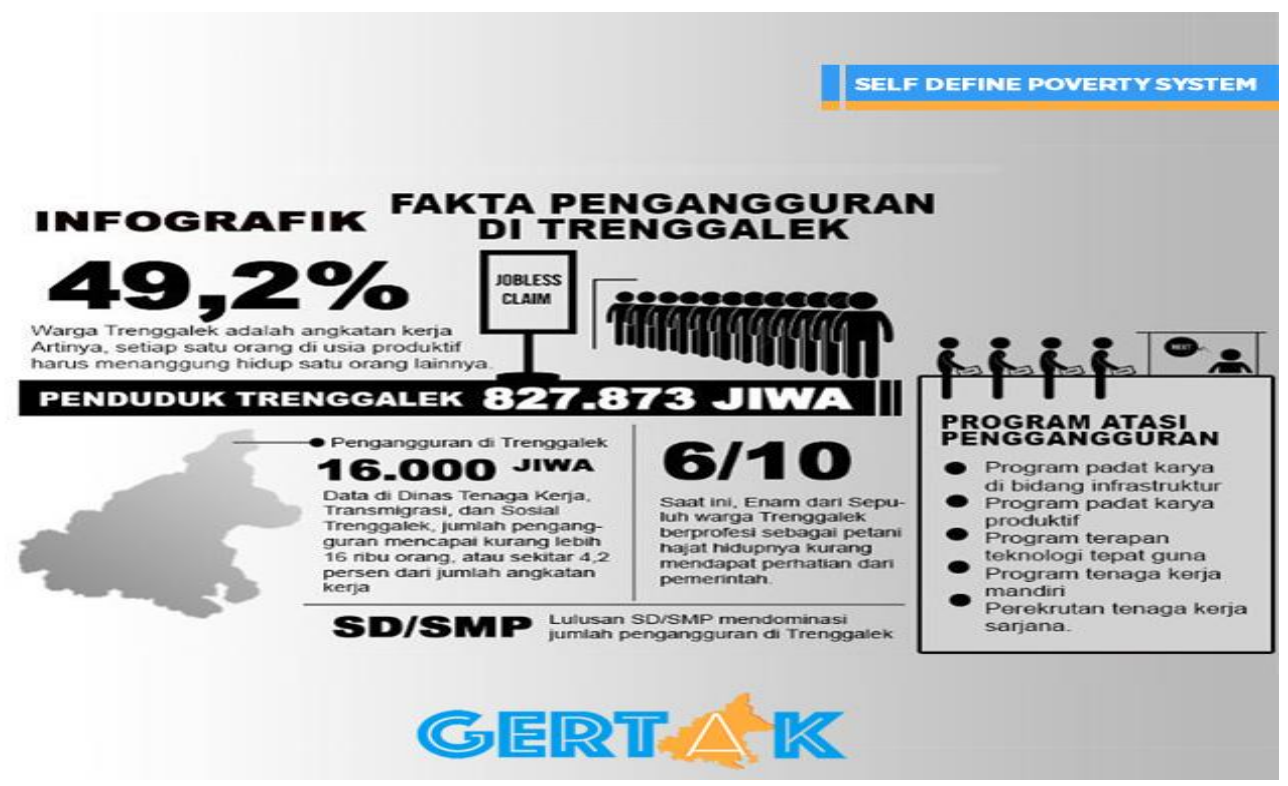

Sumber: $\quad$ http://poskogertak.id/faktapenangguran-di-trenggalek-2016/

Setelah pilkada bupati 2015, hal ini menjadi pekerjaan rumah yang harus segera diselesaikan dan tidak lagi memiliki waktu banyak. Karena Kabupaten Trenggalek sudah memasuki darurat dalam hal kemiskinan di wilayah Provinsi Jawa Timur. Kemudian pemerintah kabupaten Trenggalek, serta DPRD bekerjasama untuk dapat merumuskan sebuah program yang bertujuan untuk dapat menekan angka kemiskinan yang nantinya akan berdampak kepada kesejahteraan masyarakat Kabupaten Trenggalek.

Inovasi Pelayanan program GERTAK (Gerakan Tengok Bawah Masalah Kesmiskinan) Kabupaten Trenggalek

Inovasi program yang dilaksanakan oleh Kabupaten Trenggalek pada pelayanan menanggulangi kemiskinan melalui GERTAK yaitu inovasi metode pelayanan. Menurut Muluk (2008, h.45) inovasi metode pelayanan yaitu perubahan baru dalam hal berinteraksi dengan pelanggan atau cara baru dalam memberikan pelayanan.

Pada awal tahun 2017 akhirnya Pemerintah Kabupaten Trenggalek membuat suatu terobosan sebuah program untuk dapat mengatasi masalah kemiskinan, yaitu dengan program GERTAK (Gerakan Tengok Bawah Masalah Kesmiskinan) sebuah gerakan untuk terus menengok atau memantau ke bawah (masyarakat miskin) untuk dapat menaggulangi atau 
menuntaskan masalah kemiskinan dan juga kesenjangan sosial/manusia antara kaya dan miskin. Sebelum nya istilah GERTAK ada karena adanya perbincangan saat rembug bersama dengan wakil bupati Trenggalek, karena untuk dapat mengatasi permasalahan kemiskinan harus lah serius dan tegas. Maka dari itu wakil bupati membuat gebrakan tersebut untuk dapat mengatasi kemiskinan dan kesenjangan sosial/manusia.

Sebelumnya, bukan hanya pemerintah daerah saja yang fokus dalam mengentaskan kemiskinan. Menteri Sosial juga terus membuat terobosan dan berbagai program dalam mencapai tujuan untuk mengentaskan kemiskinina dan juga kesejahteraan masyarakat secara menyeluruh. Fokus pada bidang perlindungan dan juga jaminan sosial, terdapat beberapa program seperti Program Keluarga Harapan (PKH), kemudian di bidang penangan fakir miskin dan program bantuan pangan non-tunai (BPNT) yang juga dapat disinergikan dengan program pengentasan kemiskinan dibeberapa daerah di Indonesia. Kerjasama dan penangan yang serius lah yang akan menjadi solusi dari penangan kemiskinan ini, dengan menjalin kerjasama yang baik antara pemerintah pusat dan juga pemerintah daerah maka dengan berjalan nya waktu masalah kemiskinan akan daat teratasi.

Setelah meluncurkan program GERTAK pemerintah kabupaten Trenggalek banyak mendapatkan apresiasi, baik dari Menteri Sosial dan juga anggota DPRD. Hal tersebut sangatlah diapresiasi karena, Kabupaten Trenggalek telah mampu membuat terobosan baru yang tujuan nya fokus kepada pengentasan kemiskinan dan juga pemerataan kesejahteraan sosial di Kabupaten Trenggalek. Anggota DPRD berpendapat bahwa program ini belum ada sebelumnya pada daerah-daerah lain. GERTAK juga bukan hanya bertujuan kepada pengentasan kemiskinan, namun program ini juga untuk dapat melakukan pemerataan kesejahteraan masyarakat baik dari segi pendidikan dan juga kesehatan. Tidak semata-mata hanya didasarkan dari fokusnya pemerintahan daerah namun juga berdasaean diskusi dengan melibatkan masyarakat langusng yaitu yang diwaliki oleh tokoh masyarakat dan ketua-ketua RT di seluruh wilayah Kabupaten Trenggalek.

Kemudian sumber bantuan yang didapatkan dari program GERTAK selain dari anggaran daerah yang dimiliki oleh Kabupaten Trenggalek, anggaran juga didaptakn dari beberapa sumbangan sukarela anggota DPRD (legislatif) dan beberapa program CSR dari 
beberapa perusahaan swasta yang diberikan untuk kabupaten Trenggalek. Selain dari pemerintah terkait, komunitas dan Badan Amil Zakat Nasional (Baznas) yang memebantu untuk mengsukseskan program tersebut. Untuk dapat memudahkan masyarakat menjangkau program tersebut, pemerintah membuat kan sebuah posko GERTAK yang diperuntukan untuk menjangkau beberapa hal, seperti masalah kekurangan eokono, masalah pendidikan dan juga kesehata. Untuk dapat menangani masalah kemiskinan yang bersumber dari kekurangan ekonomi pemerintah memberikan beberapa hal untuk dapat membangkitkan ekonomi masyarakat. Hal tersebut diwujudkan dalam beberapa hal, seperti :

1. Melakukan pendampingan kepada masyarakat seperti membrikan pendidikan kerajinan tangan ddengan memanfaatkan hasil alam sekitar. Karena telah kita ketahui, bahwa masyarakat kabupaten Trenggalek berpenghasilan dari berkebun.

2. Melakukan pendataan yang disebar melalui beberapa metode. Seperti data yang diperoleh dari ketua RT setempat, dan juga pendaatan melalui survei yang dilakukan oleh Pemerintah Kabupaten Trenggalek. Supaya tidak terjadi suatu kesalahan dalam penetapan program GERTAK tersebut.

3. Melakukan pemantauan masyarakat yang teah dibelaki ilmu untuk menghasilkan sebuah nilai jual atau dapat meningkatkan penghasilan supaya terus terfokus untuk mencapai kesejahteraan masyarakat seperti tujuan dari program GERTAK itu sendiri.

Dalam melakukan pendataan pemerintah Kabupaten Trenggalek juga mempunyai strategi tersendiri untuk dapat mencakup semua lapisan dan mendata keluarga miskin dengan teliti, dengan membentuk tim yang dinamakan TKPK (Tim Koordinasi Penanggulangan Kemiskinan) yang kemudian berkoodinasi langsung dengan SKPD Kabupaten Trenggalek seperti gambar berikut : 


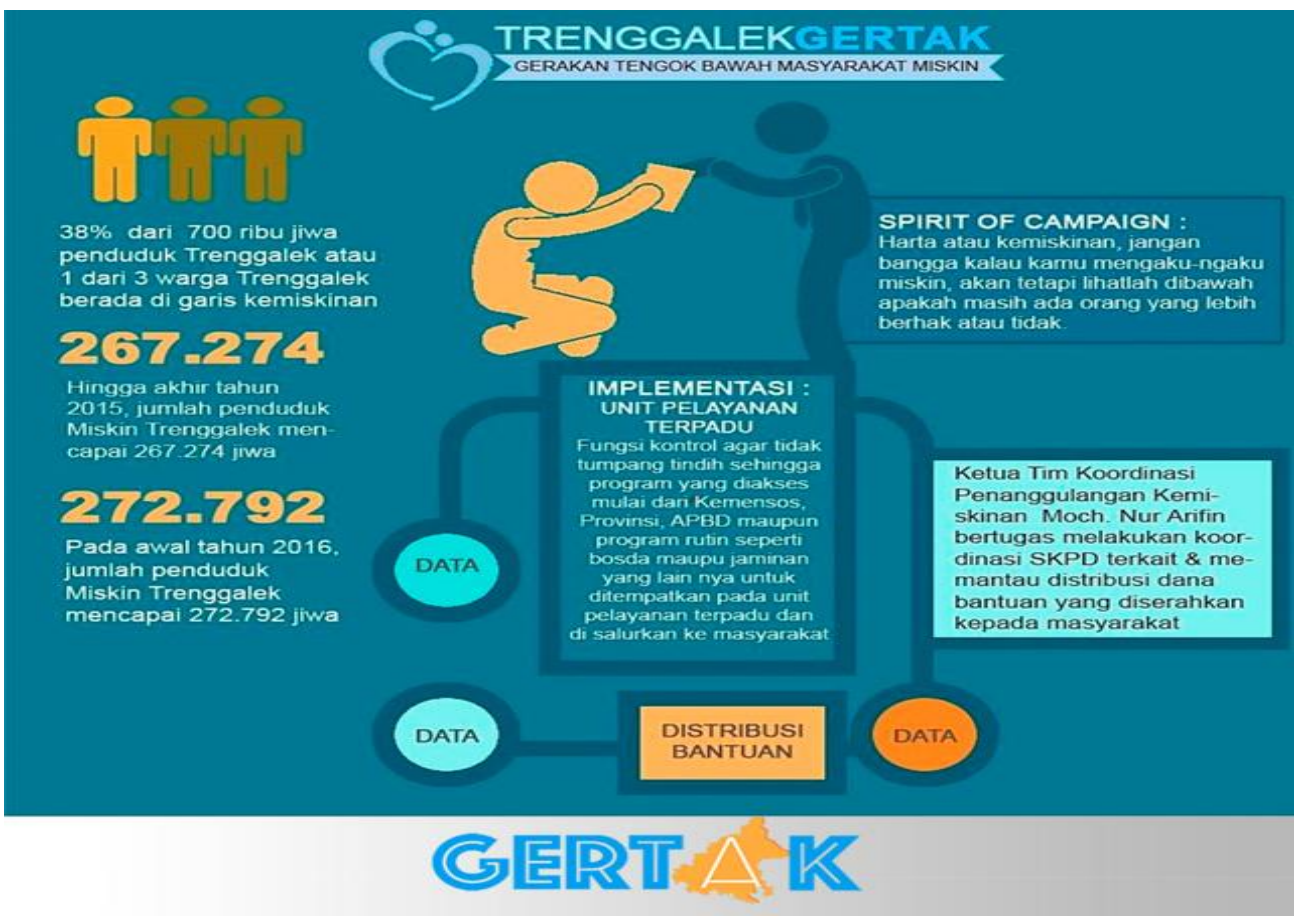

Sumber:http://poskogertak.id/pembentukan-satgas-tkpk/

Tidak hanya melakukan pendataan seperti yang dilakukan oleh tim TKPK, namun pendaatan juga dapat dilakukan dengan memanfaatkan zaman digital yaitu dengan menggunakan media sosial sebagai sarana pengaduan hal apa saja yang masih belum dapat tercukupi untuk kesejahteraan masyarakat Kabupaten Trenggalek, seperti gambar berikut :
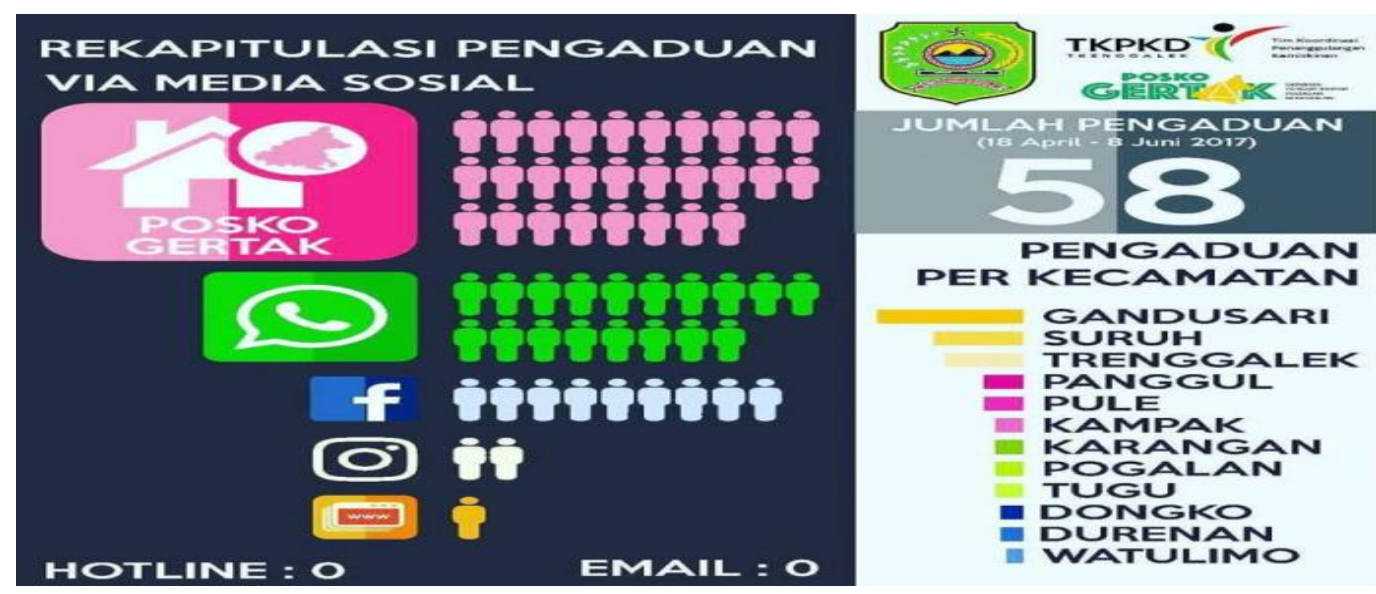

Sumber:http://poskogertak.id/infografik-pengaduan-posko/ 
Melalui grafik tersebut dapat terlihat jelas bahwasan nya pengaduan paling banyak dilakukan langsung melalui posko GERTAK, dimana masyarakat bisa langsung mendatangi posko dan juga megadukan kesejahteraan apa yang masih belum didapatkan.

Berjalannya program ini merupakan salah satu upaya yang nyata dari pemerintah Kabupaten Trenggalek dalam menangani ataupun menuntaskan masalah kemiskinan, karena program GERTAK saat ini banyak mendaptkan pengharaan sebagai upaya dan juga inovasi pemerintah daerah dalam menyelesaikan masalah daerah nya sendiri, terlebih untuk menuntaskan kemiskinan yang bertujuan untuk pemerataan kesejahteraan masyarakat. Selain bisa mengentaskan kemiskinan, program ini juga sebagai salah satu bentuk inovasi yang dilakukan dengan nama yang menarik namun implementasi yang sangat baik. Terhitung sejak tahun 2015-2016 Trenggalek mengalami peningkatan dalam jumlah kemiskinan, namun semenjak 2017 dan adanya program GERTAK, angka kemiskinan tersebut menjadi menurun. Hal ini dibuktikan dengan penghargaan yang di peroleh Kabupaten Trenggalek yang sudah berhasil mengimplementasikan program ini sehingga menekan angka kemiskinan dan juga mulai merasatanya kesejahteraan masyarakat secara keseluruhan. Dalam hal ini impelementasi daripada Otonomi daerah yang dilakukan oleh Pemerintah Kabupaten Trenggalek juga dinyatakan berhasil, karena dengan ini dapat menanggulangi masalah kemiskinan bahkan sampai kepada pemerataan kesejahteraan masyarakat yang menjadi fokua dari program tersebut.

\section{SIMPULAN}

Berdasarkan hasil penelitian yang telah dikemukakan pada bab sebelumnya, maka dapat ditarik kesimpulan bahwa inovasi program pelayanan sertifikat tanah melalui GERTAK ditinjau dari dari tipologi sektor publik melalui aspek inovasi metode pelayanan. Hal ini dapat dilihat dari program inovasinya yaitu implementasi dan bidang pelayanannya, dilihat dari implementasinya yaitu mendapat respon baik bagi menteri sosial maupun masyarakat dalam mengentaskan kemiskinan di Kabupaten Trenggalek.

\section{Melalui program GERTAK (Gerakan Tengok Bawah Masalah Kesmiskinan)}

Kabupaten Trenggalek mampu mengentaskan maslaah kemiskinan dan juga meratakan kesejahteraan masyarakat melalui berbagai aspek, baik dari segi ekonomi, pendidikan bahkan $26 \quad$ Available online at website: http://journal.uta45jakarta.ac.id/index.php/admpublik/iex 
sampai kepada kesehatan lansia yang sangat diperhatiakn oleh Pemerintah Kabupaten Trenggalek. Hal ini membuktikan bahwa pemerintah Kabupaten Trenggalek sangat serius dan fokus dalam menjalankan tugasnya sebagai penyokong dari kebutuhan masyaraakt dan juga kesejahteraan masyarakatnya.

Hal itu mampu diwujudkan oleh Pemerintah Kabupaten Trenggalek, bukan hanya Insfrastruktur yang mulai dibangun, namun pembangunan manusia juga dilakukan. Terlihat dari implementasi program GERTAK (Gerakan Tengok Bawah Masalah Kesmiskinan) dimana masyarakat dilibatkan langsung untuk saling peduli dan juga memperhatikan masalah kesejahteraan nya dengan ikut berpartispasi dalam melaporkan data diri atau mendata masyarakat miskin, sehingga dapat langsung terinput oleh SKPD yang berkaitan untuk penanganan kemiskinan. Sehingga program GERTAK (Gerakan Tengok Bawah Masalah Kesmiskinan) dinyatakan berhasil tangani atau mengentaskan kemiskinan di Kabupaten Trenggalek dan dibuktikan oleh penghargaan yang didapatkan sebagai wujud daripada Implementasi Pelayanan Daerah Trenggalek.

\section{DAFTAR PUSTAKA}

Daerah, U.-U. N. (2014). Kementrian Agraria dan Tata Ruang/ Badan Pertahanan Nasional. Retrieved from http://www.bpn.go.id/PUBLIKASI/PeraturanPerundangan/Undang-Undang/undang-undang-nomor-23-tahun-2014-4893

Gertak, P. S. (2017, September 7). Posko Gertak . Retrieved from http://poskogertak.id/pembentukan-satgas-tkpk/

Pemerintah Kabupaten Trenggalek. (2015). Retrieved from https://www.trenggalekkab.go.id/menu?page $=53 \&$ cat $=24$

Robert. (1996). Pelayanan Publik. Jakarta: Gramedia Pustaka Utama.

Sugiyono. (2013). Metode Penelitian Kualitatif dan R\&D. Bandung: Alfabeta.

Suryawati, C. (2010). Memahami Kemiskinan Secara Multidimensional. Universitas Diponegoro. 
Trenggalek, B. P. (n.d.). Statistik Penduduk Kabupaten Trenggalek. Retrieved from https://trenggalekkab.bps.go.id/

Trenggalek, M. A. (2017, April Rabu 26). Retrieved from http://bappeda.trenggalekkab.go.id/berita-mensos-apresiasi-program-gertaktrenggalek-.html 